\title{
PENINGKATAN KUALITAS PENDIDIKAN \\ MELALUI DESENTRALISASI PENDIDIKAN
}

Toifur

Dosen Tetap Jurusan Tarbiyah STAIN Purwokerto

\begin{abstract}
Along with the passing of decentralization of education, it is the impact of government decentralization as a form of Law Number 22 of 1999. Decentralization of education is not just deconcentralization of the central government power delivered to the autonomous regions, but the decentralization of education regarding the very basic problem, namely education belongs to the people and for the people, the process of developing social capital and intellectual capacity of a nation.

In this case, the development of education sector in each autonomous region to be conducted. This means that, given the will to organize, empower, reforming the learning process and develop a local curriculum in accordance with the needs and characteristics of the local area. Success or failure of autonomy or the decentralization of education in the era of regional autonomy is determined by three factors which strongly support, namely, the central government, local governments, and schools. Each of these factors has different roles. Yet the differences are owned does not mean nothing related to each other, even the differences are a job distribution, which are mutually support and sustain a successful application in the concept of autonomy and decentralization of education. It may therefore be understood that decentralization provides an opportunity and vast opportunities for each educational unit to improve the quality of education.

Keywords: Decentralization, Education Quality, the Education Unit.
\end{abstract}

\section{Pendahuluan}

Keterpurukan Sistem Pendidikan Nasional di tanah air disinyalir mulai dikeluarkannya Inpres SDN No. 10/1973. Pemerintah mengambil alih "kepemilikan" sekolah dari masyarakat, dan mengelola sepenuhnya secara birokratik, bahkan sentralistik. Semenjak itu, "rasa memiliki" masyarakat terhadap sekolah menjadi pudar dan menghilang. Peran masyarakat yang awalnya "bertanggungjawab" berubah menjadi "berpartisipasi" terhadap pendidikan selanjutnya berubah menjadi asing terhadap sekolah. Semua 
sumber daya pendidikan ditanggung oleh pemerintah dan seolah tidak ada alasan bagi masyarakat untuk berpartisipasi dalam penyelenggaraan pendidikan di sekolah (Suryadi, 2002).

Harapan baru muncul seiring dengan digulirkannya kebijakan otonomi daerah/desentralisasi. Indradjati (2003) mengatakan bahwa otonomi daerah dilakukan karena suatu kebutuhan dengan tujuan meningkatkan kesejahteraan rakyat, pemerataan, keadilan, demokratisasi, dan mengembangkan nilai-nilai budaya lokal serta menggali potensi dan keanekaragaman daerah, bukan hanya memindahkan masalah pusat ke kabupaten dan kota. Demikian juga otonomi pendidikan bertujuan untuk meningkatkan mutu pendidikan bagi seluruh lapisan masyarakat.

Berdasar pada Undang-undang No. 22 tahun 1999 tentang Pemerintahan Daerah dan Undang-undang No. 25 tahun 1999 tentang Perimbangan Keuangan antara Pemerintah Pusat dan Daerah, desentralisasi mulai diberlakukan secara resmi pada tahun 2001. Perkembangan politik yang demikian cepat membuat kedua Undang-Undang tersebut diganti dengan Undang-Undang yang baru, yakni Undang-undang No. 32 Tahun 2004 tentang Pemerintahan Daerah dan Undang-Undang No. 33 Tahun 2004 tentang Perimbangan Keuangan antara Pemerintah Pusat dan Pemerintah Daerah (Sambas, 2010).

Desentralisasi sebagai penyerahan kekuasaan ke pemerintah daerah otonom dilakukan dalam berbagai bidang atau urusan, kecuali dalam bidang politik luar negeri, pertahanan, keamanan, yustisi, moneter, dan fiskal nasional, serta agama, yang masih menjadi urusan pemerintah pusat. Berdasarkan pasal 14 Undang-Undang No. 33 Tahun 2004 terdapat 16 (enam belas) urusan wajib yang menjadi kewenangan pemerintahan daerah kabupaten/kota sebagai urusan yang berskala kabupaten/kota. Salah satu urusan wajib itu adalah penyelenggaraan pendidikan (Sambas, 2010).

Undang-undang otonomi daerah meletakkan sebagian besar pemerintahan bidang pendidikan dan kebudayaan selama ini berada pada pemerintah pusat kepada pemerintah daerah(kabupaten/kota). Kewenangan yang tersisa pada pemerintah pusat dan propinsi hanya sebatas besarannya saja. Pergeseran struktur kewenangan sistem pengelolaan pendidikan di daerah, sebab pembangunan yang selama ini didominasi pemerintah pusat terbukti kurang efektif. Hal ini terlihat dalam kenyataan bahwa berbagai 
program investasi perluasan akses pendidikan dan peningkatan mutu yang telah dilakukan belum dapat mencapai hasil yang seperti diharapkan.

Tilaar (2003), mengemukakan bahwa UU No 22 tahun 1999 yang kemudian diganti UU No 32 tahun 2004, urusan pendidikan diserahkan kepada daerah. Hal ini berarti bahwa daerah mempunyai wewenang yang penuh dalam mengatur dan mengelola pendidikan yang ada di daerahnya. Lebih lanjut Tilaar (dalam Pikiran Rakyat, 2010), mempertegas bahwa desentralisasi pendidikan merupakan suatu keharusan. Menurut dia, ada tiga hal yang berkaitan dengan urgensi desentralisasi pendidikan. Ketiga hal tersebut adalah; (1) pembangunan masyarakat demokrasi; (2) pengembangan social capital; dan (3) peningkatan daya saing bangsa. Ketiga hal tersebut sudah lebih dari cukup untuk dijadikan alasan mengapa desentralisasi pendidikan harus dilakukan oleh bangsa Indonesia.

Berdasarkan peraturan perundang-undangan di atas sudah diatur bahwa pelaksanaan pendidikan di luar kewenangan pemerintah pusat dan harus dilakukan di daerah. Oleh karena itu, pengembangan kurikulum sebagai salah satu substansi utama dalam pengembangan pendidikan perlu didesentralisasikan, terutama kebutuhan siswa, keadaan sekolah dan kondisi daerah. Dengan demikian, daerah atau sekolah memiliki cukup kewenangan untuk merancang dan menentukan hal-hal yang akan diajarkan. Sehubungan dengan kondisi daerah dan potensi daerah di Indonesia yang cukup beragam, maka daerah perlu menggali, meningkatkan dan mempromosikan potensinya melalui pendidikan di sekolah.

Masing-masing daerah mempunyai keunggulan potensi daerah yang perlu dikembangkan yang lebih baik lagi. Keunggulan yang dimiliki oleh masing-masing daerah sangat bervariasi. Dengan keberagaman potensi daerah ini pengembangan potensi dan keunggulan daerah perlu mendapatkan perhatian secara khusus bagi pemerintah daerah sehingga anak-anak tidak asing dengan daerahnya sendiri dan faham betul tentang potensi dan nilai-nilai serta budaya daerahnya sendiri, sehingga anak-anak dapat berkembang dan berdaya potensi sesuai dengan tuntutan ekonomi global yang telah disepakati oleh pemerintah Indonesia. Diharapkan dengan ekonomi global tersebut, masing-masing daerah ingin berlomba bersaing dengan negara lain untuk memasarkan keunggulan daerahnya sendiri (Dwitagama, 2007). 
Toifur

\section{Desentralisasi Pendidikan}

Desentralisasi mengandung makna yakni proses pendelegasian, pelimpahan dan kewenangan dari pimpinan atasan ke tingkat bawahan dalam organisasi (Greenberg dan Baron, 1995). Selanjutnya, Riwukaho mengatakan bahwa melalui desentralisasi segala keputusan yang dibuat dalam tubuh organisasi didelegasikan kepada bawahannya. Pelaksanaan pendelegasian dalam rangka efesiensi dan efektivitas organisasi. Dalam dunia pendidikan desentralisasi dapat diterapkan dalam tingkatan struktur organisasi penyelenggara pendidikan mulai tingkat pusat, propinsi, kabupaten/kota hingga tingkat sekolah (Nasir, 2006).

Shepard (1975) menyatakan bahwa desentralisasi mengandung makna local self government yang secara historis didasarkan atas berbagai aspek kehidupan komunitas masyarakat yang pada gilirannya berfungsi sebagai kohesi sosial yang membentuk pola kehidupan dan tingkah laku bagi komunitas masyarakat yang bersangkutan. Desentralisasi merupakan local self government yang merupakan pengejawantahan dari modern local government yakni insitusi lokal merefleksikan urusan yang bersifat komunal melalui lembaga politik yang terpilih secara demokratis adalah trend dan gejala yang mulai muncul kembali (dalam Rafiqie, 2008).

Menurut Kjeliberg (1985) mengatakan bahwa local self government terkait erat dengan tiga perangkat nilai yakni: (1) liberty or outonomy, yakni kebebasan komunitas masyarakat lokal untuk mengembangkan diri berdasarkan preferensi mereka, yang merupakan ideologi yang sangat kuat sebagai ekspresi atas kebebasan suatu masyarakat (freedom society). Bentuk dari local self government antara lain semakin dibatasinya peran pemerintah pusat dalam hal urusan kewenangan.

Pembatasan urusan kewenangan dalam rangka memberikan kesempatan kepada pemerintah daerah untuk mengembangkan potensi sumber daya yang dimiliki daerah. Contoh pemerintah daerah diberi kewenangan dalam mengelola dan melaksanakan program pendidikan dari mulai perencanaan, pelaksanaan, pengawasan, dan evaluasi oleh pemerintah daerah pada dinas pendidikan kabupaten/kota, (2) democracy or participation, yakni adanya partisipasi aktif dari masyarakat daerah dalam ikut mengelola kewenangan yang diberikan pemerintah pusat ke pemerintah daerah. Partisipasi masyarakat dimaksudkan sebagai proses 
pembelajaran dalam berbangsa dan bernegara, dengan masyarakat ikut berpartisipasi dalam penyelenggaraan pemerintahan, serta masyarakat akan terbiasa dengan isu-isu politik yang sesungguhnya dan sangat beragam, serta masyarakat juga memahami bagaimana mencapai kompromi atas kepentingan yang berbeda.

Dengan kata lain bahwa demokrasi dan partisipasi masyarakat berkaitan erat dengan rasa solidaritas dalam suatu komunitas masyarakat daerah. Hubungan demokrasi dan partisipasi masyarakat satu dengan lainnya tidak dapatdipisahkan, dan(3)efisiensi, yakni merupakan penguatan institusi yang dalam kinerjanya mengedepankan cara yang efesien dalam menangani kesenjangan antara apa yang dibutuhkan dengan tuntutan yang berkembang dalam komunitas masyarakat, dan sambil tetap berusaha mendatangkan manfaat bagi publik. Salah satu alasan utama dipandang logis menyangkut efesiensi adalah bahwa daerah berada pada posisi yang lebih baik dalam mengimplementasikan dan mengkoordinasikan tindakan yang mencerminkan kepentingan publik dan lebih berpotensi dalam mensinergikan beragam isu-isu komunal serta lebih merupakan ekspresi dari komunitas masyarakat daerah.

Mawhood (1983) menyatakan bahwa desentralisasi merupakan prinsip pengorganisasian yang mengandung unsur devolutif (membagi), demokratis, dan politis. Sehingga yang berperan adalah pemerintah daerah dengan konsep local self development dan yang akan terjadi bukan sekedar delegation of power, akan tetapi lebih bersifat devolution of power, dimana pengambil kebijakan adalah pejabat lokal yang representatif.

Dalam tulisan ini mengambil pendapat Mawhood. Makna local self development merupakan pemberdayaan masyarakat daerah (termasuk di dalamnya pejabat daerah, tokoh masyarakat daerah dan elit politik daerah) dalam berpatisipasi dalam rangka pensuksesan program pendidikan. Program pendidikan yang dilaksanakan sesuai dengan kebutuhan dan potensi daerah. Delegation of power pejabat daerah, dalam hal ini bupati yang mendelegasikan kepada dinas pendidikan, dan devolution of power pembagian tugas dalam lingkup dinas pendidikan. Kepala dinas pendidikan membagi tugas dengan jajaran di bawahnya.

Menurut Huda (1999) bahwa di negara yang telah maju seperti Amerika Serikat, konsep desentralisasi diterapkan pada berbagai tingkatan, 
yakni: (1) kelas (guru kelas); (2) kepala sekolah; (3) kabupaten (distrik); (4) Negara bagian, dan pemerintah pusat. Masing-masing tingkatan mempunyai batas kewenangan sesuai dengan tugas, tanggungjawab, dan tujuan yang ingin dicapai.

\section{Potensi Desentralisasi bagi Pengembangan Pendidikan}

Desentralisasi pendidikan di Indonesia merupakan peluang yang sangat baik untuk meningkatkan demokratisasi pendidikan, efisiensi manajemen pendidikan, dan mutu pendidikan. Dengan desentralisasi pendidikan daerah terpacu untuk memberikan pelayanan pendidikan yang baik kepada semua anak, termasuk anak-anak yang berada di daerah terpencil dan anak-anak kurang beruntung, minimal sesuai tuntutan wajib belajar pendidikan dasar 9 tahun (Sambas, 2010).

Dengan adanya desentralisasi pendidikan daerah dapat mengembangkan potensi wilayahnya sesuai dengan situasi dan kondisi setempat. Salah satu kebijakan yang dapat dikembangkan adalah membuat kurikulum sekolah yang berbasis keunggulan lokal dan global. Desentralisasi pun mendorong terjadinya efisiensi manajemen pendidikan, karena sebagian besar wewenang pengelolaan pendidikan, baik perencanaan, pelaksanaan, pembiayaan dan pengendalian penyelenggaraan pendidikan diserahkan kepada pemerintah daerah, yang disesuaikan dengan keadaan, kebutuhan, keinginan, dan kemampuan masing-masing daerah. Dengan wewenang yang besar dalam pengelolaan pendidikan, pemerintah daerah pun terdorong untuk menggali berbagai potensi daerah dan mendorong partisipasi masyarakat untuk membantu membiayai pembangunan pendidikan di daerahnya. Sebaliknya, partisipasi masyarakat dapat dibangkitkan jika manajemen pendidikan di daerah atau sekolah dapat dilaksanakan secara efisien, transparan, dan akuntabel, serta tanggap terhadap kebutuhan, dan keinginan masyarakat.

Desentralisasi pendidikan di Indonesia merupakan peluang bagi peningkatan mutu kegiatan belajar mengajar di sekolah. Dengan kata lain, ia merupakan peluang bagi peningkatan mutu pendidikan di setiap daerah. Hal ini karena perhatian terhadap peningkatan mutu guru, peningkatan mutu manajemen kepala sekolah, peningkatan sarana dan prasarana pendidikan, pembiayaan pendidikan menjadi lebih baik jika dikelola oleh para 
pejabat pendidikan yang ada di daerah. Pada akhirnya, tujuan desentralisasi pendidikan adalah pada pemerataan mutu pendidikan yang meningkat ini.

Kebijakan desentralisasi pendidikan untuk mencapai harapan seperti di atas didukung oleh berbagai potensi baik berupa keputusan politik di tingkat pusat maupun daerah, gagasan-gagasan pendidikan yang inovatif, maupun kondisi nyata di daerah. Keputusan politik yang sangat mendukung adalah dicantumkannya ketentuan dalam UUD 1945 tentang anggaran minimal pendidikan sebesar $20 \%$. Amanat konstitusional ini bukan hanya menjadi kewajiban bagi pemerintah pusat untuk memenuhinya, tetapi juga mendorong pemerintah daerah untuk menyediakan anggaran pendidikan yang cukup tinggi pula bagi pembangunan pendidikan di daerahnya.

Potensi berikutnya adalah adanya kebijakan penciptaan lembagalembaga kemasyarakat yang bernuansa lebih demokratis dalam mendukung pendidikan di daerah dan sekolah, yakni dewan pendidikan dan komite sekolah. Dewan Pendidikan yang berada di tingkat kabupaten/kota (beberapa juga ada di tingkat provinsi) merupakan sebuah lembaga independen yang anggotanya mencerminkan tokoh-tokoh yang peduli pada pendidikan. Dewan pendidikan memiliki peran strategis, misalnya berperan sebagai pemberi pertimbangan dan dukungan terhadap pihak eksekutif dan legislatif dalam hal pendidikan, melakukan pengawasan terhadap pelaksanaan kebijakan pendidikan oleh eksekutif, dan berperan pula sebagai penghubung antara legislatif, eksekutif dan masyarakat pada umumnya.

Sementara itu, komite sekolah (kadang disebut dengan nama lain seperti dewan sekolah atau majlis madrasah) merupakan sebuah organisasi yang keanggotaannya terdiri atas perwakilan orang tua siswa, guru, dan tokoh masyarakat yang peduli pendidikan, termasuk dari kalangan dunia usaha. Lembaga ini berperan sebagai mitra kerja pihak sekolah dalam memajukan pelayanan pendidikan di sekolah secara lebih demokratis, partisipatif, transparan dan akuntabel.

Gagasan lainnya yang sejalan dengan desentralisasi pendidikan adalah manajemen pendidikan yang berbasis masyarakat (communitybased management) dan manajemen berbasis sekolah (school-based management). Nielsen sebagaimana dikutip Indradjati (2003) memberikan definisi umum tentang pendidikan berbasis masyarakat sebagai "pendidikan yang sebagian besar keputusan-keputusannya dibuat oleh masyarakat." 
Dari pengertian ini dapat difahami bahwa pendidikan berbasis masyarakat itu intinya adalah keterlibatan masyarakat dalam pengambilan keputusan pada penyelenggaraan pendidikan, bukan sekedar pada sumbangan modal atau dana bagi pendidikan saja.

Ada berbagai alasan yang mendasari diterapkannya manajemen pendidikan berbasis masyarakat (community-based education) di Indonesia. Pertama, kebijakan otonomi daerah yang mendorong diterapkannya desentralisasi pendidikan, sehingga daerah dan masyarakat diberikan peluang lebih besar untuk mengambil keputusan dalam bidang pendidikan. Kedua, keinginan pemerintah mendemokrasikan kehidupan masyarakat sipil Indonesia (demokratisasi masyarakat madani), termasuk demokratisasi dalam penyelenggaraan pendidikan.

Ketiga, keterbatasan dana pendidikan pemerintah, terutama akibat krisis politik dan ekonomi yang berkepanjangan, sehingga pemerintah kurang mampu untuk membiayai pendidikan di seluruh Indonesia secara optimal. Keempat, keanekaragaman masyarakat Indonesia, sehingga pendidikannya kurang efektif jika dikelola secara sentralistik oleh pemerintah tanpa melibatkan partisipasi masyarakat. Kelima, pada kenyataannya sejak dulu masyarakat telah berpartisipasi dalam penyelenggaraan pendidikan di Indonesia.

Manajemen berbasis sekolah merupakan bentuk alternatif pengelolaan sekolah dalam rangka desentralisasi pendidikan, yang ditandai adanya kewenangan pengambilan keputusan yang lebih luas di tingkat sekolah, partisipasi masyarakat yang relatif tinggi, dalam kerangka kebijakan nasional. Keleluasaan pengambilan keputusan pada tingkat sekolah dimaksudkan agar sekolah dapat mengoptimalkan pengelolaan sumber daya dengan mengalokasikannya sesuai dengan prioritas program serta agar sekolah dapat lebih tanggap terhadap kebutuhan setempat yang ditunjang dengan sistem pendukung seperti keterampilan mengelola (managerial skills), keterampilan memperoleh dan memberikan informasi (informatical skills), serta bertumpu pada kerjasama dengan masyarakat (community-based relation).

Dalam manajemen berbasis sekolah unsur partisipasi masyarakat merupakan hal yang sangat penting. Salah satu keberhasilan manajemen berbasis sekolah adalah kemampuan sekolah untuk mengajak masyarakat 
berpartisipasi dalam mendukung penyelenggaraan pendidikan. Potensi pendukung desentralisasi pendidikan lainnya yang sejalan dengan keterlibatan masyarakat dalam pendidikan adalah banyaknya sekolah yang diselenggarakan oleh masyarakat yang tidak menggantungkan pada biaya dari pemerintah, misalnya sekolah-sekolah agama yang diselenggarakan masyarakat. Adanya sekolah-sekolah tersebut menjadi salah satu kekuatan pendukung bagi desentralisasi pendidikan.

\section{Pelaksanaan Desentralisasi Pendidikan di Indonesia}

Desentralisasi pendidikan telah diterapkan di Indonesia sejak tahun 2001. Meskipun belum terlalu lama, namun kita dapat mengungkapkan beberapa hal positif dan negatif dalam pelaksanaannya. Beberapa hal yang dapat dilihat dari sisi positif pelaksanaan desentralisasi pendidikan adalah: banyaknya daerah (terutama daerah yang kaya) yang memiliki semangat memajukan pendidikan bagi rakyatnya, misalnya dengan meningkatkan anggaran pendidikan pada APBD; menyederhanakan dan mempersingkat birokrasi pendidikan di daerah; meningkatnya inisiatif dan kreativitas daerah dalam mengelola pendidikan yang lebih memungkinkan tercapainya pemerataan pendidikan pada daerah-daerah terpencil; meningkatnya partisipasi masyarakat dalam mendukung pendidikan (terutama pada daerah yang menjadi penerapan gagasan manajemen berbasis sekolah dan masyarakat), dan sebagainya.

Sementara itu, selain hasil positif yang sudah terlihat, ternyata dalam hal-hal lainnya pelaksanaan desentralisasi pendidikan masih belum memuaskan. Hasil pengkajian percepatan pembangunan pendidikan dalam rangka desentralisasi pendidikan yang dilakukan oleh Direktorat Pendidikan TK dan SD (2002) menunjukkan bahwa pelaksanaan desentralisasi pendidikan di Indonesia belum mampu membawa peningkatan bagi pengembangan pendidikan di daerah. Dengan kata lain, keadaan pengembangan pendidikan di daerah masih belum menunjukkan perbedaan yang berarti, atau sama saja, antara sebelum dan sesudah dilaksanakan desentralisasi pendidikan. Bahkan desentralisasi pendidikan dalam hal tertentu justru malah menimbulkan kesulitan baru dibandingkan dengan keadaan sebelumnya (Sambas, 2010). 
Menurut Suyanto desentralisasi dalam bidang pendidikan akan memasuki bahaya kalau tidak ada proses penanganan yang sinergis antara pemerintah pusat dan daerah. Ironisnya, saat ini ada kecenderungan daerah tak mau melakukan koordinasi dengan pemerintah pusat. Fenomena lainnya ditemukan fakta-fakta sebagai berikut: (1) ketergantungan daerah akan dana dari pusat masih tinggi. Kondisi ini disebabkan rendahnya kemampuan keuangan yang dimiliki oleh banyak daerah sangat terbatas; (2) rendahnya komitmen dan kesadaran pendidikan yang dimiliki pengambil kebijakan di daerah. Kondisi ini sering menimbulkan munculnya kebijakan yang kontraproduktif dengan semangat desentralisasi pendidikan dan nilai-nilai demokrasi, misalnya mutasi pejabat atau guru secara sewenang-wenang oleh dinas pendidikan sebagai akibat intervensi dari penguasa daerah. Dalam www.rakyataceh.com mencatat bahwa desentralisasi pendidikan menjadi mesin penghancur pendidikan di Aceh. Dikatakan, praktek otonomi pendidikan, pada pelaksanaannya justru menyebabkan pendidikan Aceh hancur terutama di tingkat kabupaten/ kota, serta cenderung disalahgunakan oleh para raja -raja kecil ditingkat dua. Seperti halnya melakukan mutasi dan pemindahan guru secara semena-mena dengan tidak mempertimbangkan resiko yang ditimbulkan; (3) rendahnya kinerja pengelolaan pendidikan baik di tingkat birokrasi pendidikan di kabupaten/kota, kecamatan, dan di tingkat sekolah. Kondisi ini disinyalir disebabkan oleh kualitas sumber daya manusia yang tidak memadai; (4) pemerintah daerah belum secara serius melakukan pembangunan dan pemeliharaan aspek fisik sekolah ini, khususnya untuk sekolah dasar, mungkin karena pemerintah daerah kurang perhatian atau karena tidak memiliki dana yang memadai. Banyak kasus bangunan sekolah roboh karena usia; (6) pemerintah daerah juga masih belum mampu mengangkat kesejahteraan guru; (8) munculnya fanatisme sempit kedaerahan; (9) dalam hal prestasi siswa desentralisasi pendidikan belum mampu meningkatkan prestasi siswa, karena tidak ada perbedaan prestasi siswa antara sebelum dan sesudah berlakunya desentralisasi pendidikan. Dalam kaitannya dengan prestasi belajar siswa, hasil ujian nasional baik SMP maupun SMA menunjukkan banyak daerah yang kelulusannya rendah. Hal ini menunjukkan pula bahwa desentralisasi pendidikan di beberapa daerah belum dapat meningkatkan prestasi belajar siswa. Dengan kata lain, 
desentralisasi pendidikan belum mampu meningkatkan mutu pendidikan; (10) hubungan kemitraan antara stakeholders pendidikan belum mampu mendorong perkembangan pendidikan, karena belum adanya regulasi yang mempunyai kekuatan hukum, mengatur kewenangan dan kekuasaan pemerintah, masyarakat dan orang tua siswa; belum dikembangkannya wadah yang memungkinkan banyak pihak saling bertemu, berdiskusi, dan membangun komitmen bersama, dan; belum dikembangkannya upayaupaya untuk memotivasi orang tua, masyarakat, dan yayasan-yayasan penyelenggara pendidikan untuk menjalin hubungan sinergis dan saling menguntungkan dengan pemerintath (Pito, 2010). Kondisi ini sering ditunjukkan dengan pertentangan orang tua dan pihak sekolah.

Melihat fenomena di atas menunjukkan bahwa secara umum pelaksanaan desentralisasi pendidikan di Indonesia belum sesuai dengan harapan. Desentralisasi pendidikan yang sejatinya memiliki potensi yang luar biasa bagi pengembangkan pendidikan namun pada tataran realitas memiliki banyak persoalan. Perlu ada koreksi dan solusi agar bagaimana desentralisasi pendidikan dapat mewujudkan tujuan pendidikan nasional yaitu masyarakat yang cerdas dan berbudi pekerti luhur.

\section{Meningkatkan Kualitas Pendidikan melalui Desentralisasi Pendidikan}

Pelaksanaan desentralisasi pendidikan di Indonesia sebagaimana diuraikan di atas tampak masih banyak memiliki kelemahan yang perlu dibenahi. Desentralisasi pendidikan yang secara konseptual sangat baik untuk meningkatkan efisiensi manajemen pendidikan, peningkatan pemerataan layanan pendidikan dan peningkatan mutu pendidikan tentunya harus benar-benar dapat dilaksanakan dengan baik, sehingga harapan ideal dari penerapan desentralisasi pendidikan tersebut dapat tercapai. Untuk menunjang keberhasilan pelaksanaan desentralisasi pendidikan di Indonesia perlu ada berbagai upaya yang sinergis antara lain sebagai berikut:

- Sosialisasi secara berkelanjutan akan pentingnya pendidikan. Desentralisasi pendidikan akan dapat berjalan baik ketika masyarakat menyadari betul akan arti penting sebuah pendidikan. Hal ini perlu dilakukan karena masih banyak masyarakat yang belum "melek" pendidikan. Sosialisasi pentingnya pendidikan dapat dilakukan oleh 
siapa saja, khususnya oleh dinas pendidikan, dewan pendidikan, LSM pendidikan, dan PGRI. Sosialisasi pendidikan dapat dilakukan melalui media elektronik maupun cetak.

- Kerja sama yang sinergis dalam pengembangan pendidikan. Sekalipun otonomi daerah memberikan wewenang yang lebih luas kepada pemerintah daerah kabupaten/kota, namun dalam pengembangan pendidikan masih tetap diperlukan kerja sama yang harmonis antara pemerintah Pusat, pemerintah provinsi, dan pemerintah kabupaten/ kota. Desentraliasi/otonomi daerah tidak perlu menimbulkan fanatisme kedaerahan yang sempitsehingga mempersulit dinamika pengembangan pendidikan. Desentraliasi pendidikan perlu tetap mengacu kepada kepentingan dan wawasan, serta standardisasi nasional.

- Peningkatan komitmen pengambil kebijakan terhadap pembangunan pendidikan. Desentralisasi pendidikan dapat berjalan dengan baik jika ada komitmen yang kuat dari lembaga legislatif maupun eksekutif di daerah dalam menyediakan anggaran daerah yang sangat memadai bagi pembangunan pendidikan di daerah. Selain itu, peningkatan sumber daya pengelola pendidikan di daerah juga sangat diperlukan untuk memacu percepatan pembangunan pendidikan tanpa selalu tergantung pada pemerintah pusat. Dalam hal ini peranan dan kemandirian Dewan Pendidikan sebagai mitra bagi legislatif dan eksekutif di daerah perlu ditingkatkan, tanpa harus bergantung pada bantuan dari pusat.

- Penggalangan partisipasi masyarakat melalui konsensus. Partisipasi masyarakat dalam membiayai pendidikan sangat menunjang bagi keberhasilan desentralisasi pendidikan. Dalam hal ini pemerintah daerah harus mampu menciptakan kesepakatan atau konsensus dengan masyarakat untuk mendukung penyelenggaraan pendidikan di daerahnya. Konsensus ini dapat dicapai melalui dialog dengan berbagai golongan di masyarakat yang memiliki perhatian terhadap penyelenggaraan pendidikan, misalnya dengan partai politik, organisasi massa keagamaan, PGRI, para ahli pendidikan dari perguruan tinggi, dewan pendidikan, komite sekolah, dan tokoh-tokoh perorangan yang peduli akan pendidikan. Oleh karena itu, pihak pemerintah daerah perlu aktif mendekati berbagai pihak tersebut. Untuk mendorong partisipasi masyarakat yang luas, maka penerapan gagasan manajemen berbasis 
sekolah dan berbasis masyarakat perlu ditingkatkan (Sambas, 2010).

- Peningkatan kualitas sumber daya manusia. Peningkatan kualitas sumber daya manusia untuk menyelenggarakan pendidikan, baik di bidang perencanaan, pengembangan kurikulum, manajemen sekolah, evaluasi, keahlian bidang studi dan lain-lainnya perlu dilakukan oleh setiap daerah agar penyelenggaraan pendidikan oleh daerah benarbenar bisa dilaksanakan dengan baik. Hal ini dapat dilakukan dengan mengirimkan para pejabat pendidikan di daerah untuk melanjutkan studi ke jenjang S2, S3, atau mengirimkan ke pelatihan/penataran yang terprogram.

- Pemberian bantuan pusat untuk daerah miskin. Sekalipun dengan desentralisasi pendidikan tanggung jawab pemerintah pusat menjadi berkurang dalam membiayai penyelenggaraan pendidikan, namun pemerintah pusat hendaknya tetap memberikan bantuan khusus untuk menunjang daerah-daerah yang miskin, misalnya melalui Dana Alokasi Khusus (DAK) bidang pendidikan atau block grant lainnya. Sebab jika derah-daerah miskin tidak dibantu secara khusus, maka desentralisasi pendidikan bukannya akan membawa peningkatan pendidikan bagi masyarakat di daerah itu, mungkin bahkan akan menurunkan kualitas dan kuantitas partisipasi pendidikan masyarakatnya. Hal ini pun perlu dilakukan untuk mencegah terjadinya kesenjangan yang mencolok dalam prestasi pendidikan antara daerah kaya dengan daerah miskin.

- Monitoring dan evaluasi berkelanjutan. Kebaikan dan kelemahan penyelenggaraan desentralisasi pendidikan harus segera dapat diketahui agar dapat dilakukan peningkatan bagi yang telah ada atau perbaikan-perbaikan bagi yang masih memiliki kelemahan. Oleh karena itu, pihak pemerintah pusat, pemerintah daerah ataupun pihak lain dapat melakukan monitoring dan evaluasi yang berkelanjutan terhadap pelaksanaan desentralisasi pendidikan. Bafadal (Nasir, 2006) mengatakan bahwa prinsip-prinsip pembangunan pendidikan di kabupaten dan kota sebaiknya adalah sebagai berikut: (1) pengembangan program pendidikan di kabupaten jangan bersifat tambal sulam, melainkan secara sistemik yang dimulai dari pengembangan visi, misi, dan aksinya, (2) program pengembangan pendidikan di kabupaten/kota hendaknya menganut pola whole school development, 
yaitu pengembangan pendidikan di suatu daerah hendaknya menyentuh seluruh komponen sistem pendidikan, (3) setiap program pengembangan pendidikan seharusnya didasarkan pada pemetaan yang lengkap, baik pemetaan lembaga-lembaga, pendidikan, dan juga pemetaan lapangan kerja. Berdasarkan pemetaan tersebut, kabupaten/ kota dapat mengembangkan berbagai program cerdas pembangunan pendidikan yang betul-betul sesuai dengan aspirasi dan kebutuhan masyarakat banyak.

\section{Penutup}

Desentralisasi pendidikan di Indonesia tidak dapat dipungkiri adalah imbas nuansa politik yang kental sebagai upaya demokratisasi dan upaya menampung aspirasi masyarakat/daerah, serta sebagai upaya mencegah terjadinya disintegrasi bangsa. Desentralisasi pendidikan semestinya bukan hanya ingin menciptakan kesan demokratisasi di bidang pendidikan, melainkan harus pula membawa dampak positif bagi peningkatan kualitas belajar dan mengajar di sekolah dan luar sekolah.

Oleh karena itu, desentralisasi pendidikan hendaknya didukung oleh kesadaran dan partisipasi tinggi dari masyarakat terhadap penyelenggaraan pendidikan, juga didukung oleh sumber daya yang bermutu dari para penyelenggara pendidikan di daerah.

\section{Daftar Pustaka}

Greenberg, J. \& Baron, R.A. (1995). Behavior in Organization. Englewood. Cliffs N.J. Prentice.

http://alexpito.wordpress.com/2010/06/10/mal-praktek-di-bidang-pendidikan.

http://rakyataceh.com/index.php?open=view\&newsid=20311\&tit=Berita +Utama+-+Desentralisasi+Pendidikan+Tak+Sesuai+Harapan.

http://dedidwitagama.wordpress.com/2007/11/07/pendidikan-berbasiseunggulan-lokal-global.

http://sambassalim.com/pendidikan/desentralisasi-pendidikan.html.

Huda, N. (1999). Desentralisasi Pendidikan dan Permasalahannya. Malang: IKIP 
Indradjati. (2003). Menuju Masyarakat Belajar Menggagas Paradigma Baru Pendidikan, Jakarta: Logos Wacana Ilmu.

Kjeliberg. (1995). The Changing Values of Local Government. ANNALS: AAPSS.

Mawhood. (1983). Local Government In The Third World. Cichester: John Wiley \& Sons.

Nasir, M. (2006). Kebijakan Publik dalam Konteks Otonomi Daerah; Studi Kasus di Kabupaten Pasopati. Disertasi (tidak diterbitkan). PPs Universitas Negeri Malang.

Rafiqie, M. (2008). Implementasi Kebijakan di Era otonomi Daerah (Studi Multi Situs Pada Tiga Dinas Pendidikan di Kabupaten Kawasan Tapal Kuda. Disertasi (tidak diterbitkan), PPs Universitas Negeri Malang.

Suryadi, A. (2002). Anggaran Pendidikan Sebuah Ideologi. Kompas, Edisi 17 Desember 2002.

Tilaar, A.H. (2003). Kekuasaan dan Pendidikan; Suatu Tinjauan dari Perspektif Kultural, Magelang: Indonesiatera.

-------- (2010). Desentralisasi Pendidikan di Era Otda. Pikiran Rakyat, Edisi 22 Januari 2010. 